\title{
IGG ANTIBODIES TO BETA-LACTOGLOBULIN AND COW'S MILK PROTEIN INTOLERANCE IN DOWN SYNDROME*
}

\author{
Pinella Failla, Concetta Barone, Rosa Pettinato, Corrado Romano. \\ Department of Pediatrics, Oasi Institute, Troina, Italy.
}

\begin{abstract}
Cow's milk protein intolerance (CMPI) is the most frequent food intolerance in infancy. Its incidence ranges from 0.3 to $7.5 \%$, according to different diagnostic criteria and clinical features. The diagnosis of CMPI is generally based on the level of IgG antibodies to beta lactoglobulin. An association of insulin-dependent diabetes mellitus (IDDM) with CMPI has been reported. CMPI in subjects with Down syndrome (DS) has been investigated by Nespoli et al. (1993) and Reichelt et al. (1994). We assayed IgG antibodies to betalactoglobulin, by the ELISA-method, in 78 subjects with Down syndrome and 97 mentally retarded and home-reared control subjects. Gastrointestinal disorders and IDDM was ruled out in both groups. Eleven (14.1\%) and 5 $(5.1 \%)$ subjects among Down syndrome group and control group respectively, were put on a CMP-free diet, and showed relief of symptoms and normalization of IgG antibodies after 6-21 months. In conclusion, CMPI appears to be more frequent in Down syndrome versus the control group and the specificity of $\lg G$ antibodies approaches $100 \%$ in our study.
\end{abstract}

Keywords: Down syndrome, beta lactoglobulin, $\operatorname{IgG}$ antibodies

* From a paper presented at the 6th World Congress on Down Syndrome, Madrid, Spain, October 1997.

\footnotetext{
Introduction

Cow's milk protein intolerance (CMPI) is the most frequent food intolerance during infancy. Its incidence ranges from 0.3 to $7.5 \%$, depending upon diagnostic criteria and clinical features (Walker-Smith, 1975; Stintzing \& Zetterstrom, 1979; Host, 1994). The absence of a reliable and specific test and the large variability of symptoms has produced many different diagnostic criteria. The serum assay of IgG antibodies to betalactoglobulin is one of the few available tests for the diagnosis of CMPI. The association between insulin-dependent diabetes mellitus (IDDM) and CMPI, and the increased frequency of antibodies to beta-lactoglobulin in the serum of patients with IDDM has been reported (Dahlquist et al., 1992; Vaarala et al., 1996). Few papers on CMPI in people with Down syndrome have been published.
}

Nespoli et al. (1993) reported increased titres of antibodies to casein and beta-lactoglobulin. Reichelt et al. (1994) found high titres of antibodies to several food proteins, such as gliadin, casein, alpha-lactalbumin, beta-lactoglobulin and ovalbumin. Because IgA antibodies were increased, and only IgG antibodies to casein and gliadin were raised, the hypothesis of an increased permeability of the intestinal mucosa towards these antigens arose. We assayed IgG antibodies to betalactoglobulin in the subjects with Down syndrome followed up in our Department in order to assess their association with CMPI.

\section{Subjects and Methods}

IgG antibodies to beta-lactoglobulin were assayed with the ELISA method (b-lactotest IgG, Eurospital, Trieste, Italy). The results were 
expressed as an IgG index, which is the ratio between the fluorescence signal units of the sample and the positive control multiplied by 100 . An IgG index up to 55 has been considered normal. The assay was performed on the serum of 78 subjects with Down syndrome and in 97 mentally retarded and home-reared control subjects. None of these people had gastrointestinal disease or IDDM. The groups were matched for age and sex. The first group (Down syndrome) had a mean age of 11.2 years (range of 2 months- 47 years) and a sex ratio of $1.68(\mathrm{M} / \mathrm{F})$.

\section{Results}

Eleven (14.1\%) out of 78 subjects with Down syndrome had an increased IgG index and nine $(81.8 \%)$ of them were aged below 5 years. Only five $(5.1 \%)$ out of 97 control subjects presented an increased $\operatorname{IgG}$ index and four (80\%) of them were aged below 5 years. All subjects with increased IgG index showed symptoms and/or lab exams compatible with a diagnosis of CMPI. All these subjects were given a CMP-free diet which resulted in an improvement of symptoms and normalization of the IgG index 6 to 21 months after the diet was started. In the persons with Down syndrome with an increased $\operatorname{IgG}$ index the main symptom was failure to thrive, and an increased frequency of anemia was found by the laboratory tests.

\section{Conclusions}

As already reported (Nespoli et al., 1993), we have found an increased incidence of IgG antibodies to beta-lactoglobulin in the serum of people with Down syndrome compared with a control group, and an incidence which overlaps that of the general population (Walker-Smith, 1975; Stintzing \& Zetterstrom, 1979; Host, 1994). Our most interesting result is the $100 \%$ specificity of $\mathrm{IgG}$ antibodies to beta-lactoglobulin for the diagnosis of CMPI and the increased frequency below age 5 years. IgG antibodies to beta-lactoglobulin behave differently from antigliadin antibodies which, as reported recently (Failla et al., 1996; Bonamico et al., 1996), are common in people with Down syndrome, but have low specificity for the diagnosis of coeliac disease.

\section{Correspondence}

Dr. Corrado Romano, Department of Pediatrics,

Oasi Institute, Via Conte Ruggero, 73, 94018

Troina (EN), Italy. (Phone 39-935-9361 11, Fax 39-

935-653327, E-mail cromano@oasi.en.it) 


\section{References}

Bonamico, M., Rasore-Quartino, A., Mariani, P., Scartezzini, P., Cerruti, P., Tozzi, M.C., Cingolani, M., \& Gemme, G. (1996). Down syndrome and coeliac disease: usefulness of antigliadin and antiendomysium antibodies. Acta Paediatrica, 85, 1503-1505.

Dahlquist, G., Savilhati, E., \& Landin-Olsson, M. (1992). An increased level of antibodies to betalactoglobulin is a risk determinant for early-onset type 1 (insulin dependent) diabetes mellitus independent of islet cell antibodies and early introduction of cow's milk. Diabetologia, 35, 980-984.

Failla, P., Ruberto, C., Pagano, M.C., Lombardo, M., Bottaro, G., Perichon, B., Krishnamoorthy, R, Romano, C., \& Ragusa, A. (1996). Celiac disease in Down's syndrome with HLA serological and molecular studies. Journal of Pediatric Gastroenterology and Nutrition, 23, 303-306.

Host, A. (1994). Cow's milk protein allergy and intolerance in infancy. Some clinical, epidemiological and immunological aspects. Pediatric Allergy and Immunology, 5, 1-36.

Nespoli, L., Burgio, G.R., Ugazio, A.G., \& Maccario, R. (1993). Immunological features of Down's syndrome: a review. Journal of Intellectual Disability Research, 37, 543-551.

Reichelt, K.L., Lindback, T., \& Scott, H. (1994). Increased levels of antibodies to food proteins in Down syndrome. Acta Paediatrica Japonica, 36, 489-492.

Stintzing, G., \& Zetterstrom, R. (1979). Cow's milk allergy, incidence and pathogenetic role of early exposure to cow's milk formula. Acta Paediatrica Scandinavica, 68, 383.

Vaarala, O., Klennetti, P., Savilahti, E., Reijonen, H., Ilonen, J., \& Akerblom, H.K. (1996). Cellular immune response to cow's milk beta-lactoglobulin in patients with newly diagnosed IDDM. Diabetes, 45, 178-182.

Walker-Smith, J.A. (1975). Cow's milk protein intolerance. Archives of Disease in Childhood, 50, 347. 